of the parts which apply directly to his specialty, and mure time for the study of essential branches of medicine.

None of this would matter so much if ophthalmology was the somewhat limited subject of even 50 years ago-but it has widened in a way which is quite unparalleled, and the time for mastering it has increased relatively little.

I think also that the last paragraph in my letter, in which I dealt with those who fail the Primary and go into general practice, is of particular importance. The failure rate is very high, and their future efficiency in medicine would be greatly increased by a change in the examination requirements. $-\mathrm{I} \mathrm{am}$, etc.,

London W.1. O. GAYER MORGaN.

SiR,-Of correspondence there is no end. save on the action of the editorial blue pencil. Perhaps, however, you will allow me to level the score with Mr. I. A. Tumarkin (November 23, p. 1340) at two all. $\mathrm{He}$ and $\mathrm{I}$ are agreed on the basic needs of our specialty at academic level, but he has obviously mișinterpreted some of what I said in my letter of November 2 (p. 1127), and some of his own recent assertions are short of total accuracy.

$\mathrm{Mr}$. Tumarkin says that I conceded the need for a special Primary examination. I did nothing of the sort. I conceded the need for debate by the specialist bodies and the Royal College of Surgeons. Mr. Keith Lyle has put the other side of this problem with cogency in your issue of December 7 (p. 1474), and, while remaining uncommitted, I am tending to agree with his view. Even specialists, he seems to say, should know and understand the workings of the whole man.

In his original letter $\mathrm{Mr}$. Tumarkin ascribed some of the academic shortcomings of otolaryngologists to the F.R.C.S. examination, while I attempted to refute this by noting the poor support we have from the N.H.S. and the universities. Now he goes off tangentially with misleading information about what may be expected from these sources. Although this aspect is not strictly germane to the original argument, accuracy is an advantage. It is true that the hospital boards have sums at their disposal annually for investigational work, but the total amount of money available is so trivial that it is suitable only for small nonrecurring projects, and no single department or individual can count upon a grant being renewable. In no instance, as far as I am aware, is it adequate for the creation of a permanent research appointment in any field, let alone in otolaryngology.

The statement that "universities are willing to set up chairs if an authoritative case can be made out " is an inaccurate generalization from the all-toorare particular. Universities may or may not be sympathetic to our aspirations, but like the N.H.S. they are largely dependent upon public funds. and to a less degree upon the Foundations, and each has its priorities in the cutting of the University Grants Committee cake.

$\mathrm{Mr}$. Tumarkin is also misleading when he says that the M.R.C. is eager to promote research, and that any one can approach the Foundations. What he does not say is that the policy of the M.R.C. is to father a unit devoted to a fairly limited field and if this succeeds to hand it over to a university. Nor, in regard to the Foundations, does he say that their inclination is to support isolated projects, rather than to set up chairs. In other words one has to have a project, a worker, and a location before the Foundations will help-instead of an endowed location to which a worker with a project can come, which is the logical method.

To return to our main theme. $\mathrm{Mr}$. Tumarkin evidently agrees with me that the Fellowship of a College of Surgeons is a desirable hall-mark for an otolaryngologist, and I agree with him that the requirements of the various Colleges should be aligned more closely than is the case at present. Academic facilities are a parallel need and we must interest persons in high places in this regard. As usual it turns on finance.-I am, etc.,

Ronald Macbeth.

Department of Otolaryngology,
The Radcliffe Infirmary, The Radcliffe
Oxford.

\section{Cystathioninuria and Mental Aberrations}

SIR.-I would like to comment upon your annotation (November 9. p. 1148) entitled "Cystathioninuria." The appearance of only two reports is an indication of the rarity of this condition. However, the increasingly widespread use of chromatography for urine analysis may bring to light more cases. Gjessing recently reported several cases of mild cystathioninuria associated with adrenal neuroblastoma in children. I am writing to you because I would like to hear of any cases of cystathioninuria.

Mental aberrations were observed in both the reported cases of cystathioninuria that you referred to, and there is other information which indicates that cystathionine metabolism in the brain is of importance. In 1958 Tallan. Moore, and Stein $^{2}$ found large amounts of cystathionine in human brain tissue taken at necropsy, whereas brain tissue from mammalian species other than primates contained only trace quantities of this amino-acid. This was recently confirmed by Okumura, Otsuki. and Kameyama, who. in addition. found that the cystathionine level in brain from human infants and young adults was considerably less than in older adults. Some years ago I was able to produce an experimental cystathioninuria in rats by feeding a diet deficient in vitamin $\mathbf{B}_{6 .}{ }^{4}$ Later it was shown that cystathionine accumulated in the brain and certain other tissues of the animals. ${ }^{s} \quad$ The level of cystathionine in the brain of $\mathrm{B}_{6}$-deficient rats was similar to that observed in adult human brain. ${ }^{2}$ -
The cases studied by Tallan et al.' showed neither cystathioninuria nor mental aberrations, and of all the tissues analysed only the brain contained cystathionine. However, Harris et al." roported that in their mental defective cystathionine was found not only in the brain but also in the liver and kidney. It is possible, therefore, that the urinary cystathionine arises not only in the brain but also in the peripheral tissues. We may draw an analogy between the vitamin- $\mathrm{B}_{6}$ deficient animal and the patient with cystathioninuria : both excrete cystathionine and show an accumulation of the amino-acid in peripheral tissues. The presence of cystathionine in the brain of human adults does not give rise to an excretion of cystathionine in the urine. It is evident that mental effects are only seen in cases of severe cystathioninuria. Relatives who had only moderate cystathioninuria showed no mental aberrations.

The observations that you quote on the reduction of cystathionine excretion upon administration of large doses of vitamin $B_{6}$ suggests that cystathioninuric patients require abnormally large amounts of the vitamin to maintain the full activity of the enzyme cystathionase.-I am. etc.,

\section{Department of Pharmacology, University of Oxford. \\ REFERENCES \\ 1 Giessing, L. R., Biochem. J., 1963, 89. 42P. ${ }^{2}$ Tallan, H. H., Moore, S., and Stein, W. ${ }^{42 P .}$, biol. Chem.. 1958. 230, 707. 3 Okumura. N., Otsuki, S., and Kameyama J. Biochem. (Tokyo), 1960, 47, 315 4 Hope, D. B., Biochem. J.. 1957, 66. 486. 5 J. Physiol. 'Lond.). 1958. 141, 31P. \\ D. H. H., Ann. hum. Genet., 1959, 23, 442.}

\section{Thrombocytopenic Purpura and Rubella}

SiR,- - In your leading article headed "A New Look at Rubella" (November 23, p. 1281) you ask, "... is it correct to regard rubella itself as a harmless disease?"

In reply to this question you did not mention the complication of thrombocytopenic purpura following rubella.

Clearly defined in 1949 by Ackroyd only 20) examples of this condition had been reported by $19600^{2}$ Since then, at least six examples of this complication have been seen in this hospital area, the majority of them related to the 1962 epidemic. One of the patients died. Earlier this year five cases were reported from one hospital area by Wallace." who, rightly in my opinion, suggested that many cases may go undetected.

It may be, on the other hand, that this complication is so widely known, and so frequently diagnosed following rubella, that it is seldom thought worthy of record. If this is the case. then it is perhaps surprising that no mention of it was made by yourself or your contributors.

Although the purpura may be fulminating and may occur at the height of the febrile illness, as in other infections, the 
cases seen here suggest that a timeinterval of weeks, or even months, may occur between the exanthem and the detection of frank thrombocytopenic purpura.

It seems likely that, among virus infections, rubella may have a special importance in the causation of some cases of " idiopathic" thrombocytopenic purpura, and, if this is so. its importance is surely belied at present by the scarcity of available information on the incidence of this serious complication.-I am. etc.,

\section{Department of Pathology.} General Hospital,

\section{R. A. Sladden.}

\section{REFERENCES}

1. Ackroyd. J. P.. Quart. J. Med., 1949. 18. 299. Yeur Buok of Pathology and Clinical Patholog 10601101, 1961, p. 350. Edited by W. B. Wartman. Year Book Medical Publishers, Chicago.

- Wallace. S. J., Lancet. 1963, 1. 139.

Wintrube, M. M.. Clinical Haematology. Sth ed.

ly61, D. 832 Henry Kimpion, London.

\section{Evaluation of Phenoxypenicillins}

SIR.-The carefully controlled bloodlevel study of the clinically available phenoxypenicillins by Dr. J.llian $M$. Bond and her colleagues (October 19, p. 956) rightly draws attention to the pitfalls attendant upon carrying out this type of work. Since. however. much attention is drawn to previous work from the Research Division. Pfizer Lid.. we crave your indulgence for the following remarks :

(1) In the original paper on the lahoratory assessment of propicillin' the amount of the phenoxypenicillins present in the sera from volunteers given the antihiotic was determined not only in terms of penicillin $G$ ra method described hy Kunin et al. ${ }^{2}$ for the tetracyclines and adapted to the phenoxypenicillins by Williamson et at.') hut also in terms of itself. This fact has been ignored by $\mathrm{Dr}$. Bond and her colleagues.

(2) When the lahoratory work reported by Williamson el al.' was carried out. Bunn and $K$ night" had not putlished thell tindings regarding the ideal concentration of bovine albumin that could be used as a diluent in the assay of penicillins in human serum. Grove and Randall recommend a $7 \%$ solution of bovine albumin as a diluent, and the use of $6 \%$ bovine albumin as a diluent by Williamson et al.' was. as stated under "Methods." the outcome of previous experimentation. In this context attention is drawn to the use of $3 \%$ hovine alhumin by Knudsen and Rolinson ${ }^{3}$ for the assay of phenethicillin, and of $4 \%$ bovine alhumin by

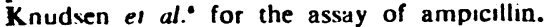
Dr. Bond and her co-workers place no emphasis upon the use of bovine albumin by these workers whilst drawing attention to the possible errors in our work following the use of this diluent.

Carefully controlled developmental work upon the technique of large plate assay has led us to adopt the principle that the vehicle for the antibiotic standard must be identical to that of the body fluid whose content of antibotic is to be determined. Each individual's premedication fluid is the ideal vehicle, but where this is inconvenient then a pool of fluid from at least six individuals appears, in our hands at least. to give reliahle results in the test systems employed. Our belief is substantiated by Bunn and Knight, ${ }^{2}$ who state " normal pooled human serum probably is the only diluent that can be used for accurate and dependable measurement of any penicillin, new or old, in human serum." All studies upon the distribution and concentration of antibiotics in body fluids undertaken by us in the last two years have been carried out using as vehicles for the antibiotic standard either pooled human serum, pooled human urine, or a pool of whatever fluid was appropriate.

(3) In our technique both the standard dispensed in $100 \%$ pooled human serum and test sera are treated in an identical manner. Three serial dilutions of the standard and of the test sera are made in such a way that all dilutions have a final concentration of $33 \%$ serum in phosphate hufter at $\mathrm{pH}$ 7. Using this test system Jackson and Williamson" ohtained the following average blood-levels (see Table) in a controlled cross over study involving 35 volunteers given $250 \mathrm{mg}$. phenoxymethylpenicillin. phenethicillin, and propicillin. It is pertinent to mention that the values for the test sera at all dilutions were almost identical, thereby showing that the dose/response curve was linear.

Total Levels of Antibiotic in Serum (ug./ $\mathrm{ml}$.) After a Single Duse of $250 \mathrm{mg}$. of a Penicillin

\begin{tabular}{lr|r|c|c|c}
\hline \multirow{2}{*}{ Penicillin } & \multicolumn{3}{|c|}{ Hours after Administration } \\
\cline { 2 - 6 } & & $\frac{1}{2}$ & 1 & 2 & 4 \\
\hline Phenoxymethylpeni- & & & & 4.42 \\
cillin K &.. & 3.42 & 2.33 & 0.72 & 0.04 \\
Phenethicillin K & $\ldots$ & 4.88 & 4.93 & 1.72 & 0.15 \\
Propicillin K &.. & 9.04 & 7.86 & 2.89 & 0.36 \\
\hline
\end{tabular}

It is to be noted that the values ohtained for phenoxymethylpenicillin and phenethicillin are almost identical to those reported by Dr. Bond. However, the values ohtained for propicillin are considerably higher and in keeping with those reported by Williamson et al.' and with those obtained by us on several occasions.

(4) Finally, whilst on the subject of microbiological assay, it should be pointed out that the technique used by us to obtain the results quoted ahove enabled an assessment of the parallelism and linearity of the assay results obtained from individual plates to be made. Knowledge of hoth these factors is of fundamental importance in the evaluation of the validity of an assay. The technique described by Lighthown and Sulizzeanu* and used by Dr. Bond does not allow these two factors to be evaluated for individual assays or groups of assays.

(5) The results of extensive experiments in these lahoratories upon the effect of $100 \%$ pooled human serum upon the minimum inhihitory concentration of the phenoxypenicillins for Stuphylococrus aureus are in agreement with those of Dr. Bond. However, since we have not ohtained the low serum levels of total propicillin reported by Dr. Bond and her colleagues we cannot accept their low rating of this antibiotic.

-We are, etc.

\section{G. M. Williamson.}

J. K. MORRISON.

P. G. D. NAYLOR.

Research Division.

Pfizer l id. Sandwich, Kent.

\section{REFERENCES}

1 Williamson, G. M.. Morricon, J. K.. and Stevens, $K$ I.. Lancet. iok1. I. 847 . Kunin. C. M. Divrnhush, A. C., and Finland, M.. o clin Inirs.. 1959. 38. 1950. ther., 1961, 11, 190.
- Grove, D. C.. and Randall, W. A." Assay Methods of A nithbotics. 1455, D. 31 . Medical
Encyclopacdia Inc.. New York.

- Knudsen, E. T., and Rotinson. G. N., Lancet, 1959. 2. 1105 .

198. and Stevens, S.. Brit. med. J., 1961. 2,

7 Jackson. D.. and Williamson. G. M., unpublished observations, 1962.

Lighibuwn. J. W., and Sultite
Hlth Org., 1957, 17, 553.

\section{Enuresis}

SiR.-Dr. I. G. Wickes and Dr. T. H. Gillison (November 9. p. 1200) both strongly advise the buzzer and would seem to imply that it is likely to be a straightforward easy procedure in the majority of cases. The following occurrences are taken from 15 consecutive cases where the buzzer was used: (1) The bell rang seven times one night. (2) Five members of the family were wakened by the bell: the patient slept ibrough. (3) A father on discovering that the boy had turned off the bell and wet his bed threatened him with a severe caning. The bed was dry thereafter.

It would seem that one of the effects of the buzzer may be to mobilize a considerable number of family tensions any of which may affect the individual. his sleep. and his habit. Our original article (September 28. p. 787) indicated that there had been isolated a group who remained "wet." The buzzer was offered to all those who lived within easy travelling distance of the hospital. Nine accepted the offer-three girls and six boys. After a further two years only one is fully dry: two have given up the buzzer. settling for one wet night in six ; one remains wet after two prolonged trials : another is improving after a third trial: four proved to be uncooperative and when last heard of were all wet. As a group they tended to ignure letters and not keep appointments. This suggests that for some adolescents either the "cure" is more distasteful than the symptoms or that their " non-conperative" attitude is now well ingrained.

In our article we wrote: " The doctor's role need not necessarily be entirely passive. and intervention designed to aid the learning process (conditioning devices, bladder-training) or to remove anxiety and unhelpful parental attitudes may be successful." Undoubtedly the buzzer can function satisfactorily in some cases. but it may also arouse considerable anxiety and is certainly not the answer in every case.- I am, etc.

Bristol 8.

R. F. BARBOUR.

SiR, - The symptom nocturnal enuresis must tax all medical practitioners who see children, yet its aetiology is obscure and its treatment haphazard. Of 399 children referred to our school and family psychiatric service last year $27 \%$ presented this symptom. so I have followed with interest the articles and correspondence on the subject in your pages (November 9. p. 1199 and preceding).

The "buzzer" we have found effective. if used properly, in most physically fit chit 